\title{
Calidolipeurus, new genus for Lipeurus megalops Piaget, 1880 (Phthiraptera: Ischnocera: Oxylipeurus-complex), with a redescription of the type species and a preliminary key to the Oxylipeurus-complex
}

\author{
Daniel R. GUSTAFSSON ${ }^{1, *}$, Lujia LEI ${ }^{2}$ \& Fasheng ZOU ${ }^{3}$ \\ ${ }^{1,2,3}$ Guangdong Key Laboratory of Animal Conservation and Resource Utilization, Guangdong Public \\ Laboratory of Wild Animal Conservation and Utilization, Guangdong Institute of Applied Biological \\ Resources, Guangzhou, Guangdong, China. \\ ${ }^{*}$ Corresponding author: kotatsu@fripost.org \\ ${ }^{2}$ Email: leilujia456@163.com \\ ${ }^{3}$ Email: pzoufs@giabr.gd.cn

\footnotetext{
${ }^{1}$ urn:lsid:zoobank.org:author:8D918E7D-07D5-49F4-A8D2-85682F00200C

${ }^{2}$ urn:lsid:zoobank.org:author:8F6D34B8-CD2D-42EE-8C17-695A22016FD8

${ }^{3}$ urn:Isid:zoobank.org:author:A0E4F4A7-CF40-4524-AAAE-60D0AD845479
}

\begin{abstract}
The chewing louse species Lipeurus megalops Piaget, 1880, is redescribed and illustrated. This species has previously been placed in the genus Oxylipeurus Mjöberg, 1910, but marked differences in preantennal structure, male and female genitalia, abdominal chaetotaxy, and structure of abdominal plates indicate that this species is not closely related to other species in this genus. We therefore erect a new genus, Calidolipeurus gen. nov. for this species. Calidolipeurus is presently monotypic, containing only Calidolipeurus megalops gen. et comb. nov. We also provide a preliminary key to the Oxylipeuruscomplex.
\end{abstract}

Keywords. Phthiraptera, Ischnocera, Oxylipeurus-complex, new genus, redescription.

Gustafsson D.R., Lei L. \& Zou F. 2020. Calidolipeurus, new genus for Lipeurus megalops Piaget, 1880 (Phthiraptera: Ischnocera: Oxylipeurus-complex), with a redescription of the type species and a preliminary key to the Oxylipeurus-complex. European Journal of Taxonomy 686: 1-15. https://doi.org/10.5852/ejt.2020.686

\section{Introduction}

The first comprehensive review of the Oxylipeurus-complex was by Clay (1938), who considered all species to belong to the same, morphologically variable, genus, Oxylipeurus Mjöberg, 1910. Within this genus, she designated six species groups, based on rough similarities in morphology. The third group comprised four species parasitizing small-bodied partridges in Southeast Asia, including Lipeurus megalops Piaget, 1880, parasitizing the crested partridge, Rollulus roulroul (Scopoli, 1786). Kéler (1958) considered this group distinct from Oxylipeurus s. str. and proposed the subgeneric name Megalipeurus Kéler, 1958. Most subsequent treatments of the Oxylipeurus-complex have followed Clay (1938) and Hopkins \& Clay (1952), and considered Megalipeurus and most other proposed genera in the Oxylipeurus-complex to be synonyms of Oxylipeurus (e.g., Ledger 1980; Price et al. 2003) 
However, in recent decades, redescriptions of several species in the Oxylipeurus-complex have been published (Mey 1990, 2010), including that of the type species Oxylipeurus inaequalis (Piaget, 1880). These indicate that Oxylipeurus s. str. is morphologically very different from most other species in the Oxylipeurus-complex, and that several genera commonly synonymized with Oxylipeurus (e.g., Price et al. 2003) should be accepted as valid. Mey $(2009,2010)$ has recently considered the genus Megalipeurus as a valid genus, including the species $L$. megalops.

We agree that all of the genera considered synonyms of Oxylipeurus in the recent checklist of Price et al. (2003) should be accepted as valid, following Mey $(2009,2010)$ and Gustafsson et al. (2020). This includes the recognition of the following genera considered synonymous with Oxylipeurus in the checklist of Price et al. (2003): Eiconolipeurus Carriker, 1945, Epicolinus Carriker, 1945, Megalipeurus Kéler, 1958, Reticulipeurus Kéler, 1958 and Talegallipeurus Mey, 1982.

However, Mey (2009) includes the species L. megalops in Megalipeurus, following its placement in Group III by Clay (1938) and in Megalipeurus by Kéler (1958). Oxylipeurus megalops is similar to other species in Megalipeurus in the presence of elongated and strongly sclerotized coni and in the general shape of the female subgenital plate, but it differs from all other species in the Oxylipeurus-complex in many significant characters (see below). We therefore here propose a new genus, Calidolipeurus gen. nov. for L. megalops.

\section{Material and methods}

All examined specimens are deposited at the Natural History Museum, London, United Kingdom (NHMUK). Drawings were made using a drawing tube attached to a Nikon Eclipse Ni (Nikon Corporation, Tokyo, Japan) and edited in GIMP (www.gimp.org). Measurements (all in $\mathrm{mm}$ ) were made from live images in NIS-Elements (Nikon Corporation, Tokyo, Japan) for the following dimensions: HL = head length (along midline); HW = head width (at temples); POW = preocular width (at preantennal nodi); $\mathrm{PRW}=$ prothoracic width; PTW = pterothoracic width; AW = abdominal width (at segment V); TL = total length (along midline, including stylus). Terminology of morphological and setal characters and abbreviations thereof follow Gustafsson \& Bush (2017).

Abbreviations used (following Gustafsson \& Bush 2017 and Gustafsson et al. 2020): $\mathrm{AL}=$ anterior lobes; as $1-2=$ anterior setae $1-2 ;$ avs $3=$ anterior ventral seta $3 ; \mathrm{C}=$ conus; $\mathrm{CL}=$ "claspers"; CLS = clypeo-labral suture; DPS = dorsal preantennal suture; DPAS = dorsal post-antennal suture; $\mathrm{E}=$ eye; $\mathrm{ES}=$ epistomal suture; $\mathrm{HM}=$ hyaline margin; $\mathrm{LAVP}=$ lateral accessory vulval plates; $m d s=$ mandibular seta; $m t s 3=$ marginal temporal seta 3 ; os $=$ ocular seta; $p o s=$ preocular seta; $p s p s=$ principal postspiracular setae; $p s t 1-2=$ parameral setae $1-2 ; s 1-7=$ sensilla $1-7$; SGP $=$ subgenital plate; SMC $=$ secondary marginal carina; $s s=$ sutural setae; $\mathrm{STY}=$ stylus; $\mathrm{VM}=$ vulval margin; vsms $1-2=$ ventral submarginal setae $1-2 ; \mathrm{Y}=\mathrm{Y}$-shaped thickening.

\section{Results}

Systematics

Order Phthiraptera Haeckel, 1896

Suborder Ischnocera Kellogg, 1896

Family Philopteridae Burmeister, 1838

Oxylipeurus-complex

Calidolipeurus gen. nov. urn:1sid:zoobank.org:act:E0395B9A-62AD-4A56-BE5B-C99CD210E7D6

\section{Type species}

Lipeurus megalops Piaget, 1880. 


\section{Diagnosis}

Based on morphological similarities, Calidolipeurus is likely most closely related to Megalipeurus, reflecting the close relationship between the hosts of the two louse genera (Wang et al. 2013). These two genera share the following characters: coni elongated in both sexes (Figs 5, 7); female subgenital plate with deep median indentation on anterior margin (Fig. 4); female vulval margin convex (Fig. 4); dorsal preantennal suture present (Fig. 5); tergopleurites II-VII medianly separated in both sexes (Figs 1-2); tergopleurites IX $+\mathrm{X}$ and XI fused (Figs 1-2).

Calidolipeurus can be separated from Megalipeurus by the following characters: marginal carina interrupted only near as 1 in Megalipeurus, but interrupted near as 1 and as2 in Calidolipeurus (Fig. 5); dorsal preantennal suture transversal in Megalipeurus, but longitudinal in Calidolipeurus (Fig. 5);
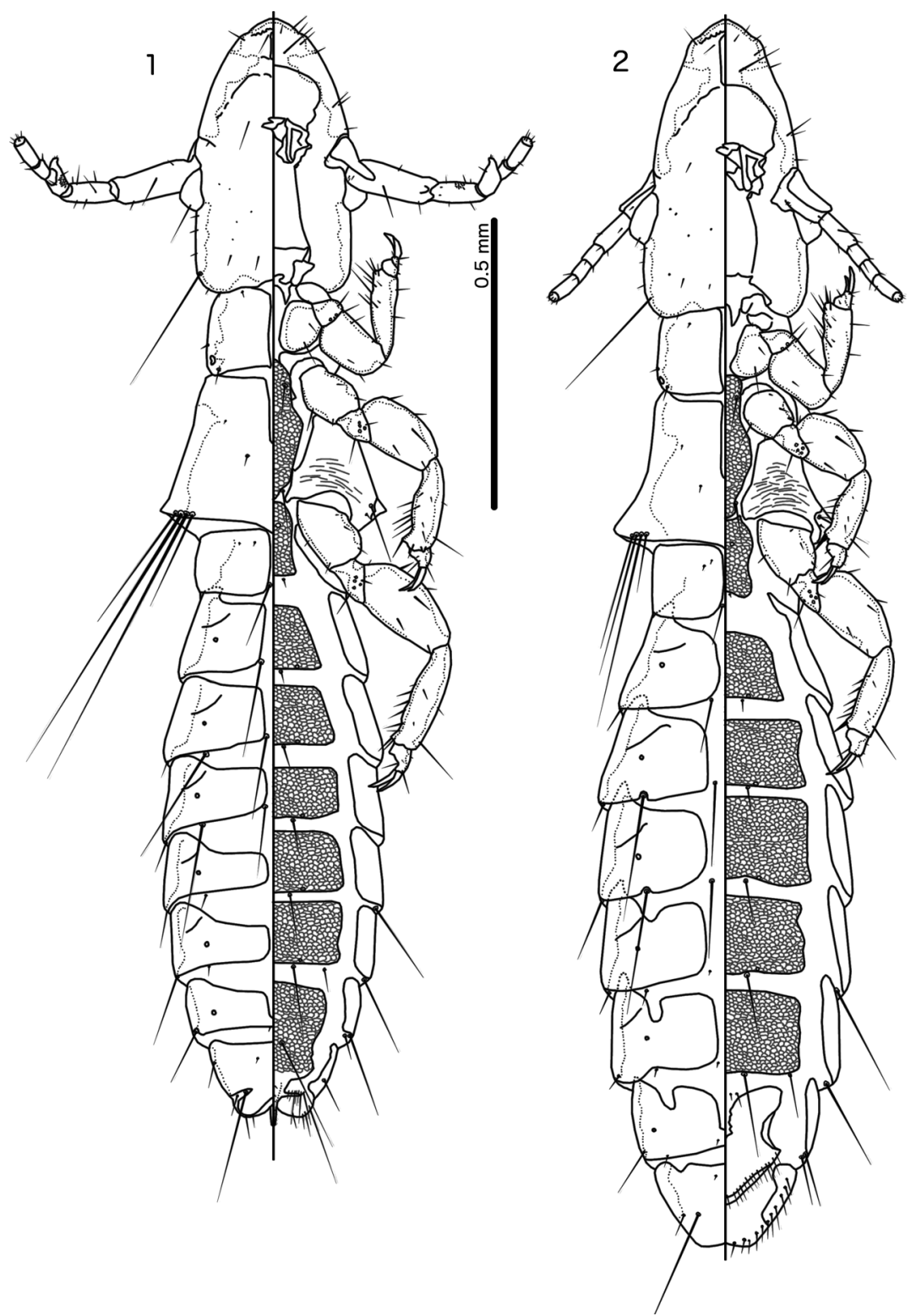

Figs 1-2. Calidolipeurus megalops (Piaget, 1880) gen. et comb. nov., based on specimens on slide NHMUK010682491 (NHMUK). 1. Habitus, $\partial^{\lambda}$, dorsal and ventral views. 2. Habitus,, , dorsal and ventral views. 
postmarginal carina extended medianly in Calidolipeurus (Fig. 5), but not in Megalipeurus; eyes gigantic in Calidolipeurus (Fig. 5), but not in Megalipeurus; preocular nodus present in Megalipeurus but absent in Calidolipeurus (Fig. 5); stylus reaches beyond distal margin of abdomen in Calidolipeurus (Fig. 3), but not in Megalipeurus; ss present on male abdominal segments VI-VII in Megalipeurus, but absent in Calidolipeurus (Fig. 1); psps present and of equal size on male tergopleurites IV-VI in Megalipeurus, but present on tergopleurites IV-VII in Calidolipeurus (Fig. 1) with those of tergopleurites VI-VII microsetae; male subgenital plate with lateral extensions following genital opening in Calidolipeurus (Fig. 3), but without such extensions in Megalipeurus; parameres very broad proximally, with overall shape roughly triangular in Calidolipeurus (Fig. 12), but with slender heads in Megalipeurus; proximal mesosome with large rounded lobes on each side in Megalipeurus, but without such lobes in Calidolipeurus (Fig. 9); gonopore with lateral hook-shaped elongations in Calidolipeurus (Fig. 11), but roughly rounded in Megalipeurus.

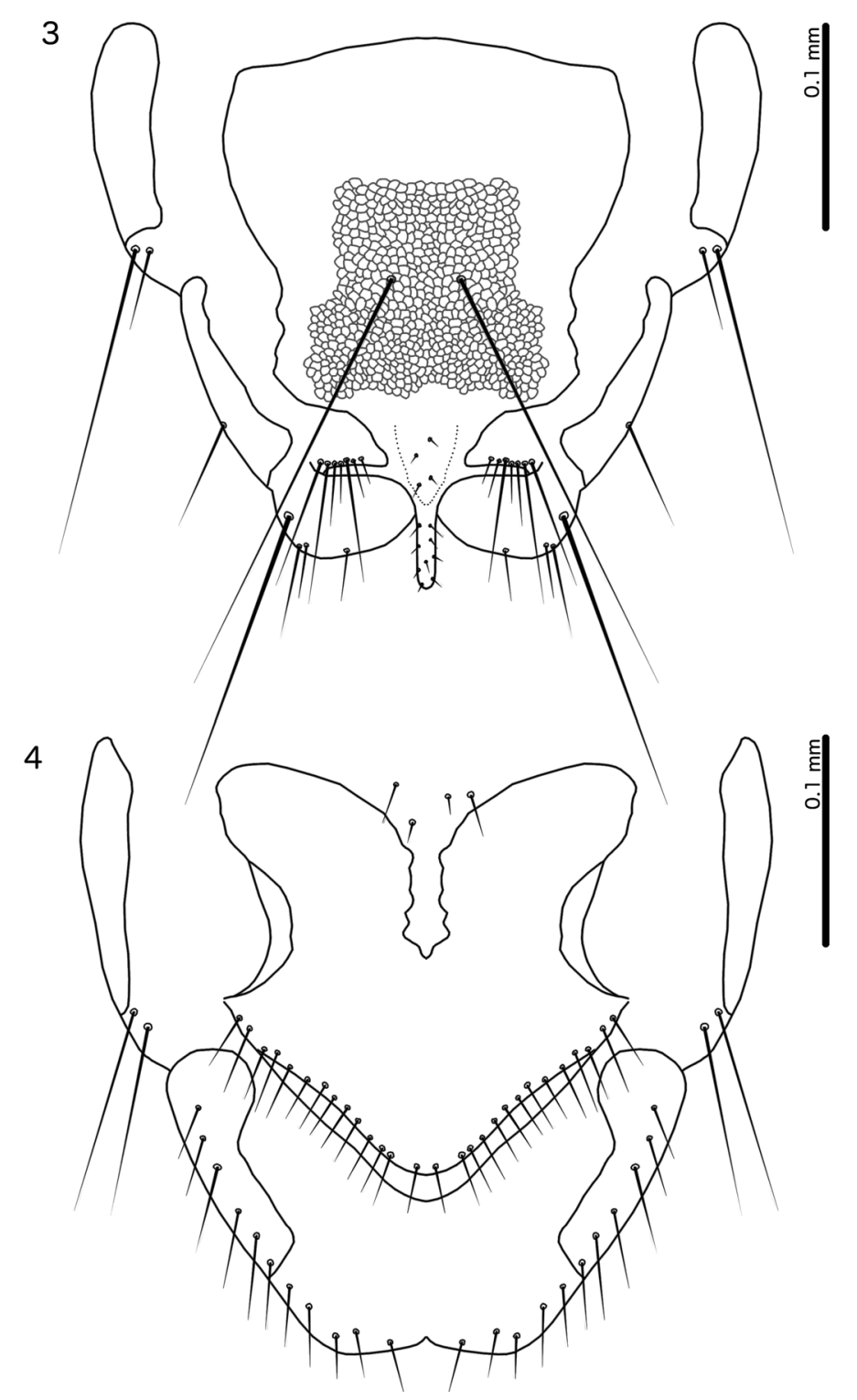

Figs 3-4. Calidolipeurus megalops (Piaget, 1880) gen. et comb. nov., based on specimens on slide NHMUK010682491 (NHMUK). 3. Male subgenital plate and terminalia, ventral view. 4. Female subgenital plate and terminalia, ventral view. 


\section{Etymology}

Calidolipeurus is constructed from the Latin 'calidus' for 'white spot in the forehead' and the genus name Lipeurus Nitzsch, 1818, commonly used for long and slender ischnocerans. This refers to the small, elongated dorsal preantennal suture of the type species, which appears white in many specimens in contrast to the otherwise brownish head. Gender: masculine.

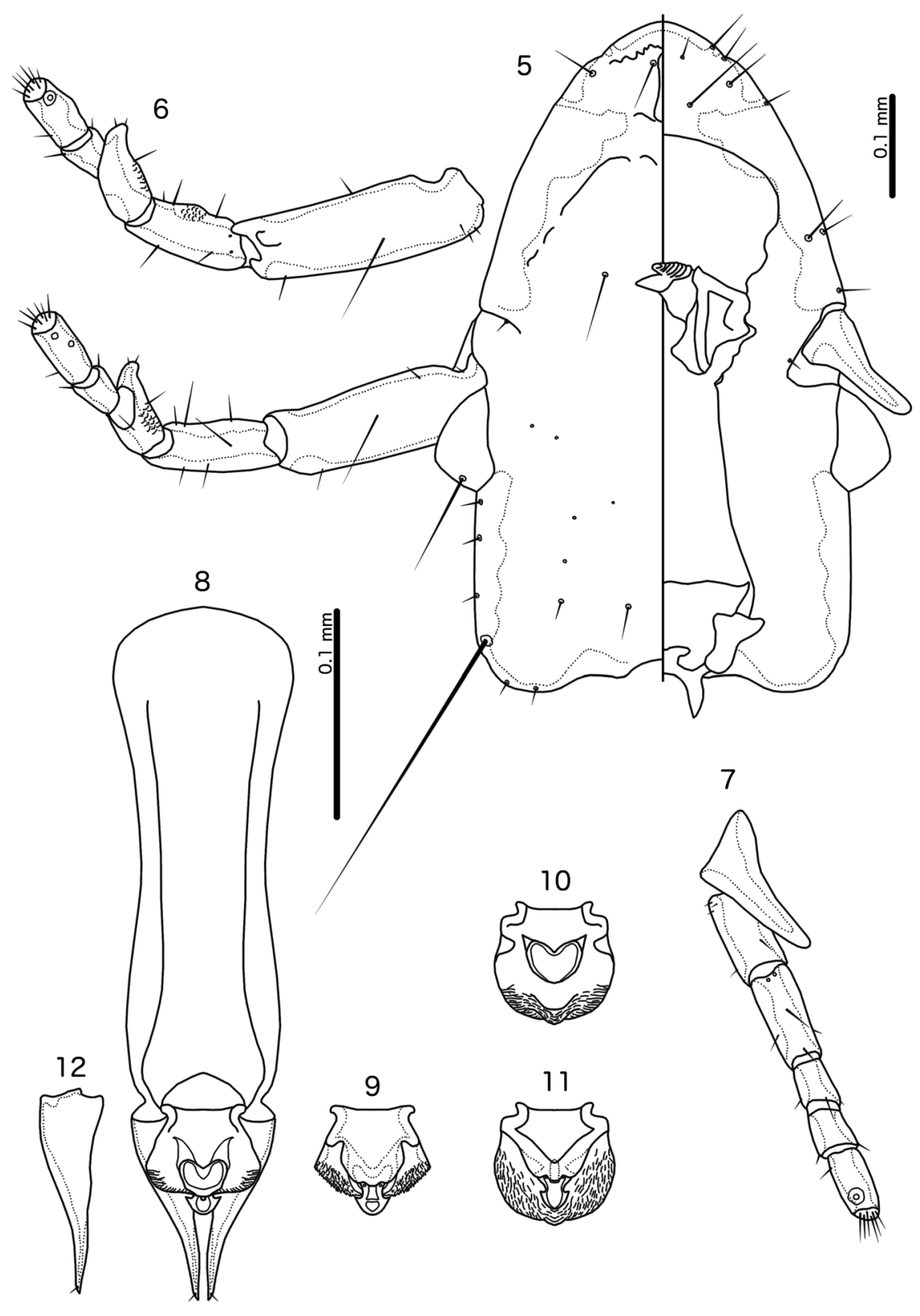

Figs 5-12. Calidolipeurus megalops (Piaget, 1880) gen. et comb. nov., based on specimens on slide NHMUK010682491 (NHMUK). 5. Male head, dorsal and ventral views. 6. Male antennae, ventral view. 7. Female antenna, ventral view. 8. Male genitalia (mesosome everted), dorsal view. 9. Male mesosome (everted), ventral view. 10. Male mesosome (not everted), dorsal view. 11. Male mesosome (not everted), ventral view. 12. Male paramere, dorsal view. Male and female antenna at same scale as male head; all genitalic elements at same scale. 


\section{Description}

\section{Both sexes}

Overall body shape elongated, 'lipeuroid' (Figs 1-2). Head longer than wide (Fig. 5). Marginal carina widening considerably anteriorly, interrupted laterally near sites of as 1 and as 2 . Frons slightly protruding; marginal carina at frons with serrated posterior margin. Dorsal preantennal suture narrow, median, longitudinal. Ventral carina uninterrupted, indistinct. Head chaetotaxy as in Fig. 5; avs3 anterior, near $v s m s 1-2 ; m d s$ not visible in all examined specimens; $s 1-3, s 5$ and $s 7$ present; $p o s$ posterior to eye; $m t s 3$ only macroseta. Coni elongated. Antennae sexually dimorphic (Figs 5-7). Eyes large. Preocular nodus absent. Marginal temporal carina slender. Dorsal postantennal suture absent.

Thoracic and abdominal segments as in Figs 1-2. Legs as in Figs 13-18; similar between sexes but some setae more slender in female than in male. Meso- and metasterna fused. Metepisterna long, with extensive striation. Tergopleurites II-VII medianly separated; tergopleurite VIII medianly continuous in posterior end; tergopleurites IX $+\mathrm{X}$ and XI fused. Sternites medianly continuous, reticulated in both sexes. Subgenital plates differ between sexes, formed by fusion of sternites VIII-IX.

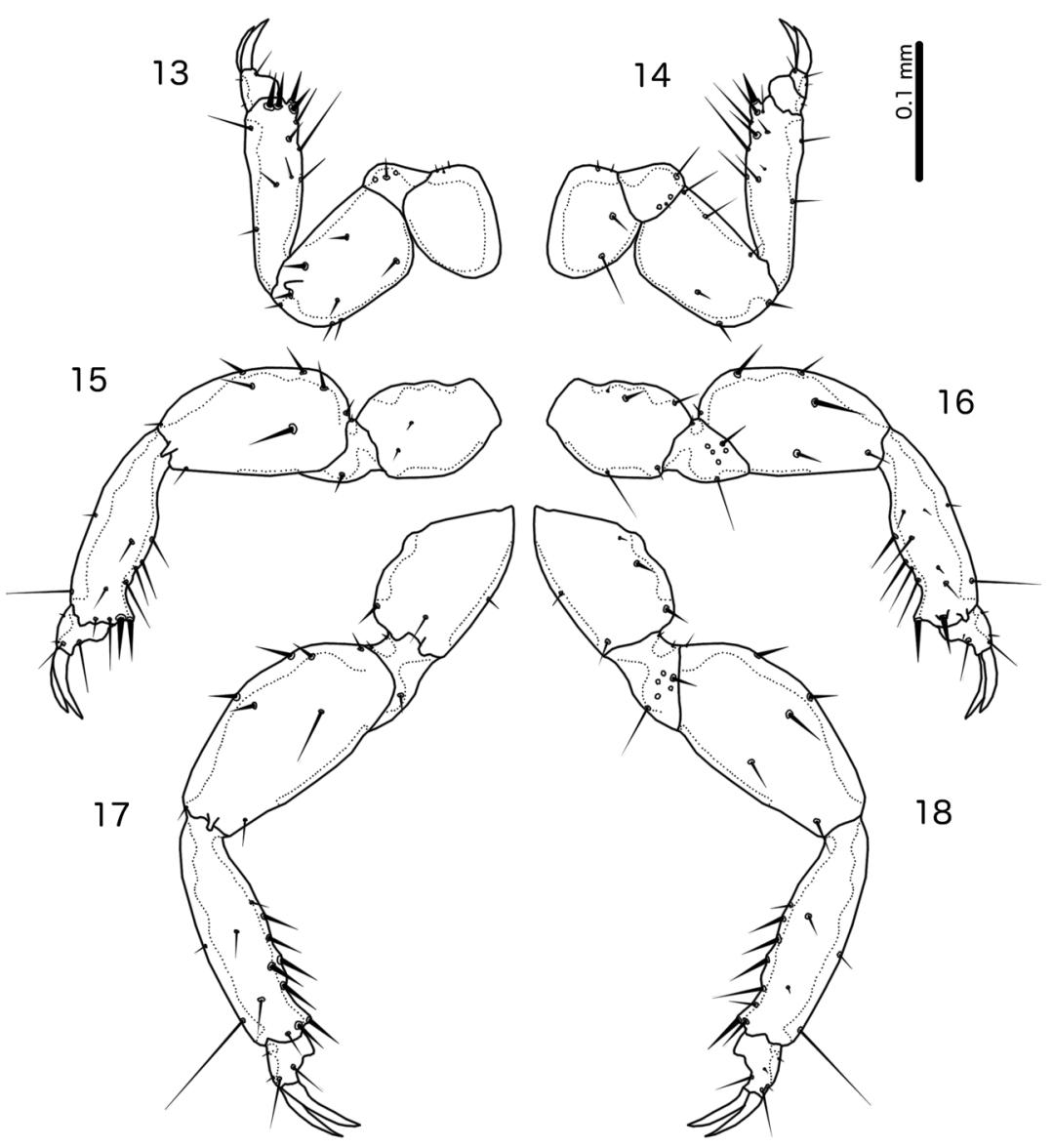

Figs 13-18. Calidolipeurus megalops (Piaget, 1880) gen. et comb. nov., based on specimens on slide NHMUK010682494 (NHMUK). 13. Male leg I, dorsal view. 14. Male leg I, ventral view. 15. Male leg II, dorsal view. 16. Male leg II, ventral view. 17. Male leg III, dorsal view. 18. Male leg, III, ventral view. 


\section{Male}

Pedicel and flagellomere I with rugose antero-dorsal surface; flagellomere with antero-dorsal claw-like elongation. Thoracic and abdominal chaetotaxy as in Fig. 1; ss present on segments II-V; psps present on segments IV-VII, those of VI-VII microsetae. Tergopleurite IX-XI with variable lateral incision reaching apertures of setae. Subgenital plate with extensive reticulation (Fig. 3), distally elongated into protruding stylus; lateral extensions on each side of base of stylus associated with anterior margin of ventral genital opening. Basal apodeme elongated, of roughly equal width, but in some specimens with concave lateral margins (Fig. 8). Mesosome largely unsclerotized, and looks different in specimens with everted or non-everted genitalia. Proximal mesosome flattened to concave, but diffuse and here illustrated approximately (Figs 8-11); on each side sinusoid thickening articulating with parameral heads. Distal mesosome roughly quadratic, with extensive folds and serrations on dorsal and ventral surfaces. Internal sclerite roughly heart-shaped (Fig. 10). Gonopore longer than wide, with lateral hook-shaped in distal end; in anterior end a dark central sclerite may be proximal part of endophallus; one small aperture on each side of presumed endophallus may be microsetae, but setae not visible in examined specimens. In everted genitalia, the gonopore extends beyond distal margin of mesosome, and rugose areas of mesosome contracted (Figs 8-9). Parameres roughly triangular (Fig. 12), median corners of heads almost touching anteriorly; median margin of anterior parameres weakly sclerotized; pst 1 not visible; pst 2 microsetae near distal end of paramere.

\section{Female}

Pedicel and flagellomere I without rugose areas and without claw-like elongation. Head chaetotaxy similar to male, but $s 7$ shorter. Thoracic and abdominal chaetotaxy as in Fig. 2; ss present on segments II-V; psps present on segments IV-VII; those on VI-VII microsetae. No lateral incision of tergopleurite IX-XI in examined specimens. Subgenital plate formed by fused sternites VIII-IX (Fig. 4); proximal margin deeply indented medianly. Vulval margin strongly convex; setae situated anterior to margin and do not form distinct sets. Subvulval sclerites absent. Lateral and posterior margins of abdominal segment IX-XI with more or less equally spaced and equal-sized setae.

\section{Host distribution}

Only known from the type host of the type species, Rollulus roulroul (Scopoli, 1786) (Galliformes: Phasianidae).

\section{Geographical range}

Indo-Malayan region, both mainland and the Indonesian archipelago.

Calidolipeurus megalops (Piaget, 1880) gen. et comb. nov. Figs 1-18

Lipeurus megalops Piaget, 1880: 675.

Esthiopterum megalops - Harrison 1916: 138.

Oxylipeurus megalops - Clay 1938: 166.

Oxylipeurus (Megalipeurus) megalops - Kéler 1958: 327 [inferred].

Megalipeurus megalops - Mey 2009: 162 [inferred].

\section{Type host}

Rollulus roulroul (Scopoli, 1786) - crested partridge (Phasianidae). 


\section{Type locality}

Madagascar [= in error]. Known from Southeast Asia (Thailand, peninsular Malaysia, Borneo).

\section{Material examined}

\section{Non-type material}

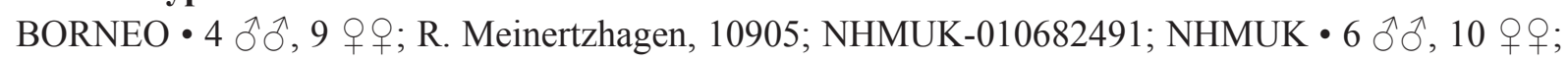

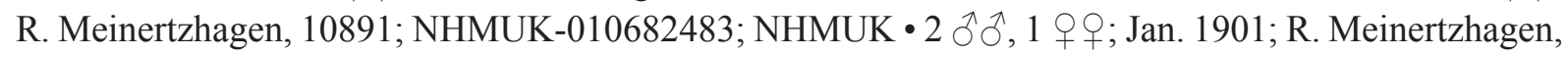
3655; NHMUK-010682490; NHMUK.

MALAYSIA • $1 \partial^{\Uparrow}, 1$ \%; Terengganu [as Trengganu]; $140 \mathrm{ft}$ a.s.1.; $102^{\circ} 0^{\prime} \mathrm{E}, 5^{\circ} 28^{\prime} \mathrm{N} ; 26$ Feb. 1974; Gn. Lawit Expedition, Brit. Mus. 1974-2; NHMUK-010682494; NHMUK.

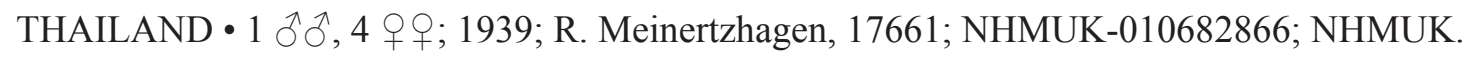

\section{Description}

See genus description.

\section{Male}

Lobes of genital opening with 3-5 mesosetae and 1-3 short setae on each side. Stylus with 12-16 microsetae ventrally or laterally (some situated near base of stylus). Measurements ( $\mathrm{n}=14$, except TL where $\mathrm{n}=13)$ : $\mathrm{TL}=1.84-2.01(1.93) ; \mathrm{HL}=0.44-0.50(0.47)$; $\mathrm{POW}=0.25-0.28(0.27) ; \mathrm{HW}=0.26-$ 0.29 (0.28); $\mathrm{PRW}=0.21-0.24(0.22) ; \mathrm{PTW}=0.35-0.41(0.38) ; \mathrm{AW}=0.34-0.41(0.37)$.

\section{Female}

Proximal margin of subgenital plate typically with two setae on each side, but placement asymmetrical and 1-3 setae may be present on each side; lateral setae about twice as long as median setae. Vulval margin with 10-15 slender setae on each side (Fig. 4). Measurements $(\mathrm{n}=25$, except AW where $\mathrm{n}=$ 24): $\mathrm{TL}=2.11-2.31$ (2.21); $\mathrm{HL}=0.49-0.53$ (0.51); $\mathrm{POW}=0.25-0.29(0.27) ; \mathrm{HW}=0.28-0.32(0.30)$; $\mathrm{PRW}=0.22-0.24(0.23) ; \mathrm{PTW}=0.37-0.43(0.40) ; \mathrm{AW}=0.40-0.46(0.43)$.

\section{Remarks}

Piaget (1880) gives as type locality Madagascar, which is well outside the range of the host species (Madge \& McGowan 2002). Clay (1938) examined Piaget's types, which she found to be identical to material from Borneo. Piaget's type locality designation is therefore here considered erroneous.

We have seen photos of the lectotype and paralectotype (at NHMUK), but not examined these specimens in person. The photo of the female lectotype does not differ from the non-type specimens we have examined.

\section{Preliminary key to the genera of the Oxylipeurus-complex}

Characters taken primarily from Clay (1938), Clay \& Meinertzhagen (1941), Carriker (1945, 1967), Emerson \& Ward (1958), Kéler (1958), Elbel \& Price (1970), Mey (1982, 1990, 2006, 2010), Gustafsson et al. (2020), and examinations of specimens. Additional groups deserving recognition at the genus level may exist, and many species of the complex are in need of further study and redescription. The genus Labicotes Kéler, 1939, may also belong to this complex, based on similarities in male and female terminalia, male genitalia, and temporal chaetotaxy between this genus and Chelopistes. This needs to be confirmed by additional studies of species of Labicotes, and the genus is not included here. 
1. Broad-headed, with width of head similar to, or wider than, length of head (Figs 19-20); temples with elongated "horns" (Fig. 19) or with prominent lateral bulges (Fig. 20)....

- Slender-headed, with head clearly longer than wide (Fig. 5); temples generally rounded, never with prominent bulging.

2. Temporal setae $m t s 1-2$ macrosetae (Fig. 20)

Trichodomedea Carriker, 1946

- Temporal setae mts $1-2$ microsetae (Fig. 19) Chelopistes Kéler, 1939

3. Dorsal preantennal suture present (Figs 5, 21)

- Dorsal preantennal suture absent or if present only visible around aperture of $a d s$ and not extending medianly (Fig. 22)

4. Dorsal preantennal suture as median, elongated oval, not expanded laterally (Fig. 5); female terminalia with marginal mesosetae distributed more or less equally around distal margin (Fig. 4); eye very large and preocular nodus absent (Fig. 5)

Calidolipeurus gen. nov.

- Dorsal preantennal suture transversal, normally reaching apertures of $a d s$ (Fig. 21); female terminalia with marginal setae gathered in the same area (Fig. 23); eye not very large (Fig. 21), and preocular nodus present

5. Clypeo-labral suture present (Fig. 24); stylus expanded distally, with small "hooks" on lateral margins (Fig. 25).

Gallancyra Gustafsson \& Zou, 2020

- Clypeo-labral suture absent (Fig. 5); stylus differing in shape, but never with lateral 'hooks'......... 6

6. Dorsal preantennal suture with postero-lateral elongations ("epistomal suture" sensu Kéler 1958) extending towards preantennal nodi (Fig. 26); hyaline margin present (Fig. 26) .

Splendoroffula Clay \& Meinertzhagen, 1941

- Dorsal preantennal suture without such extensions (Fig. 21); hyaline margin absent (Fig. 21) ....... 7

7. Dorsal postantennal suture present (Fig. 27); male genitalia asymmetrical, with mesosome much reduced (Fig. 28)

Oxylipeurus Mjöberg, 1910

- Dorsal postantennal suture absent (Fig. 21); male genitalia symmetrical, with prominent mesosome (variable, but similar to Figs 8-11)

8. Coni elongated (similar to Fig. 5); male mesosome with prominent V- or Y-shaped thickening in distal half (Fig. 29); proximal margin of mesosome with rounded lateral lobes (Fig. 29); frons convergent to median point in most species (similar to Fig. 27)...

Megalipeurus Kéler, 1958.

- Coni short (Fig. 21); male mesosome without thickening in distal half; proximal margin variable, but never with rounded lateral lobes; frons rounded

9. Male abdominal segments IX and IX $+\mathrm{X}$ with prominent postero-lateral extensions ("claspers" sensu Carriker 1945) (Fig. 30)

Eiconolipeurus Carriker, 1945

- Male abdomen without such structures Reticulipeurus Kéler, 1958

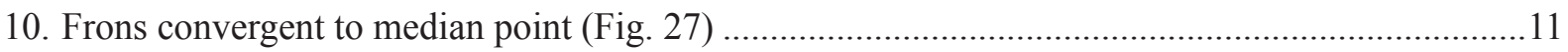

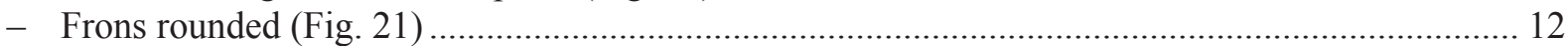

11. Male tergopleurites II-VII medianly continuous with no median indentations of anterior margin; male abdominal segments IX $+X$ and XI fused into roughly triangular cone (Fig. 31); stylus elongated and slender, in the shape of a posterior extension of the male subgenital plate (Fig. 31); female terminalia without "claspers", vulval margin more or less straight

Afrilipeurus Mey, 2010

- Male tergopleurites II-VII either divided medianly, or with median indentation of anterior margin; male tergopleurites IX $+\mathrm{X}$ and XI separate, posterior margin concave (similar to Fig. 1); stylus short and blunt (Fig. 32); female terminalia with "claspers", vulval margin deeply concave (Fig. 33) 


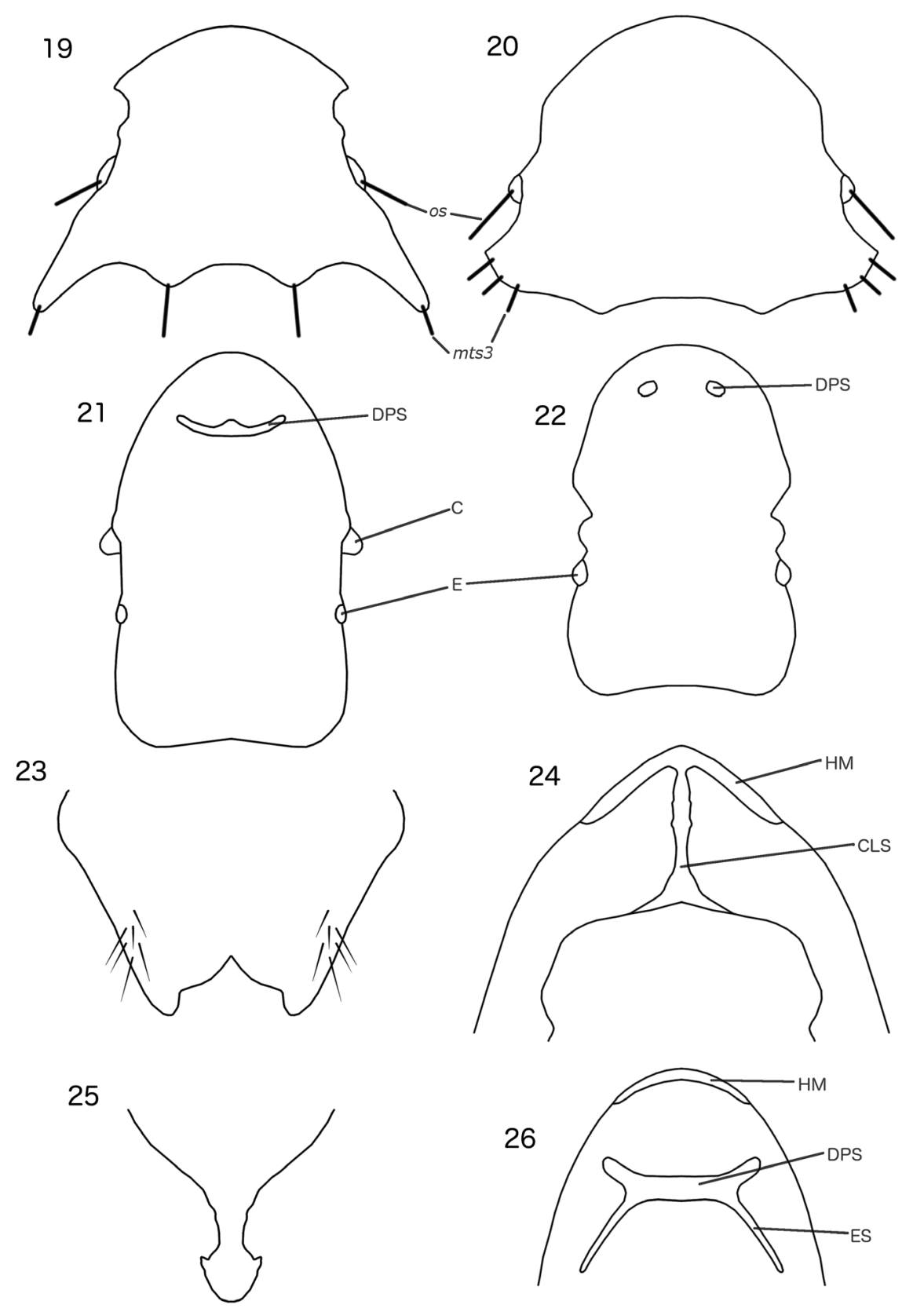

Figs 19-26. 19. Outline of head and temporal macrosetae (cut off distally) of male Chelopistes meleagridis (Linnaeus, 1758), redrawn from Kéler (1939). 20. Outline of head and temporal macrosetae (cut off distally) of female Trichodomedea setosus Carriker, 1946, redrawn from original description. 21. Outline of head and dorsal preantennal suture of male Reticulipeurus mesopelios (Nitzsch, 1866), redrawn from Gustafsson et al. (2020). 22. Outline of head and dorsal preantennal suture of male Cataphractomimus junae Gustafsson et al., 2020, redrawn from original description. 23. Female terminalia of Reticulipeurus mesopelios (Nitzsch, 1866), redrawn from Gustafsson et al. (2020); vulval margin, lateral macrosetae, and subvulval plates not illustrated. 24. Ventral view of preantennal area in Gallancyra dentata (Sugimoto, 1934) (redrawn from Gustafsson \& Zou 2020a). 25. Outline of stylus in Gallancyra dentata (Sugimoto, 1934) (redrawn from Gustafsson \& Zou 2020a). 26. Outline of preantennal area and dorsal preantennal suture of Splendoroffula ampullaceal Kéler, 1955, redrawn from Kéler (1958). Antennae not included in any illustration. Abbreviations used: C = conus; CLS = clypeo-labral suture; DPS = dorsal preantennal suture; E = eye; ES = epistomal suture; HM = hyaline margin; $m t s 3=$ marginal temporal seta 3 ; os $=$ ocular seta. Illustrations are not to scale. 

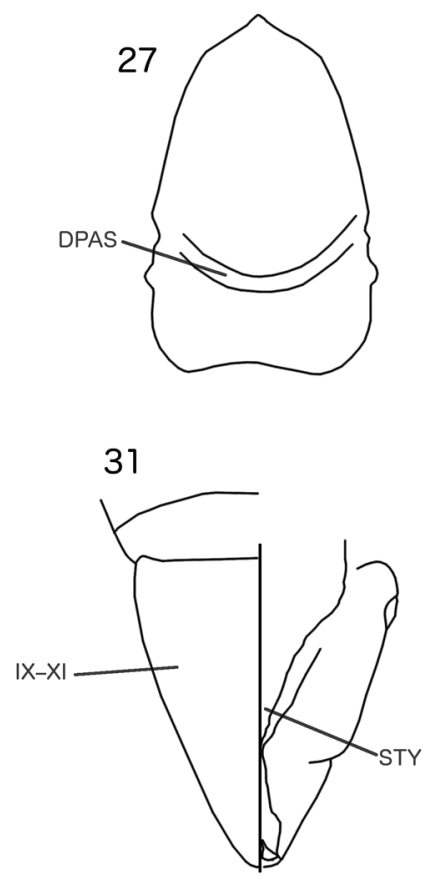

35

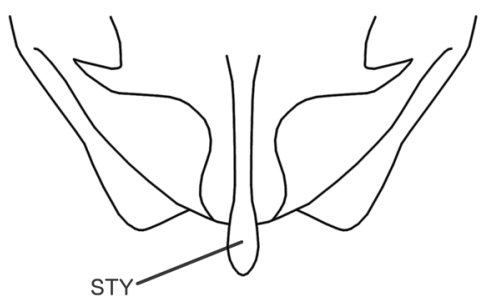

28
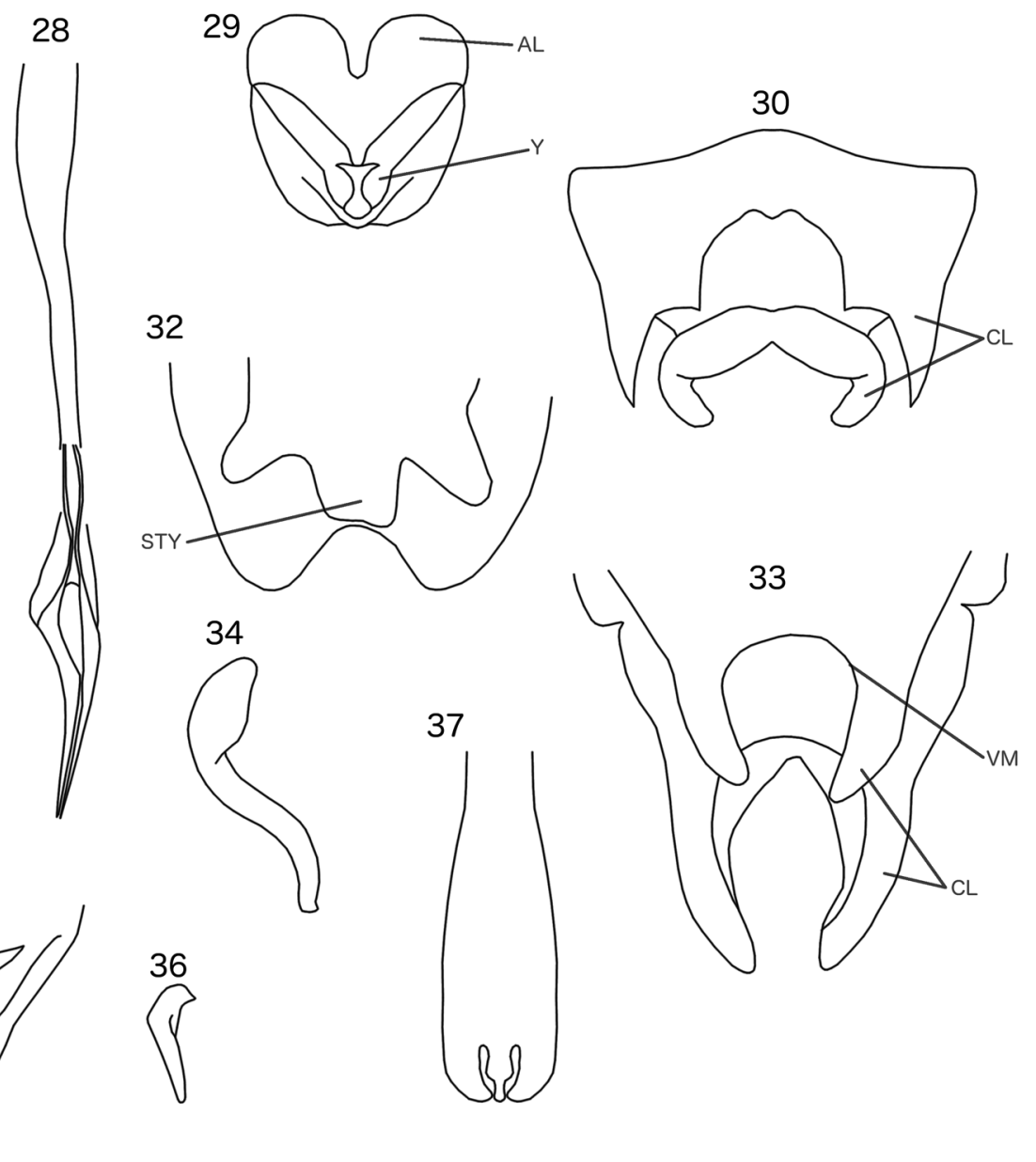

Figs 27-37.27. Outline of head and dorsal post-antennal suture of Oxylipeurus inaequalis (Piaget, 1880), redrawn from Mey (1990); original drawing asymmetrical. 28. Male genitalia of Oxylipeurus inaequalis (Piaget, 1880), redrawn from Mey (1990); some details left out for clarity. 29. Ventral view of mesosome of Megalipeurus sinensis Gustafsson et al., 2020, redrawn from original description. 30. Dorsal view of male terminalia of Eiconolipeurus melanotis Carriker, 1945, redrawn from original description; setae not illustrated. 31. Dorsal and ventral views of male terminalia of Afrilipeurus vincentei Kéler, 1953, redrawn from Mey (2010); seta not illustrated. 32. Ventral view of male terminalia and stylus of Talegallipeurus tenuis Mey, 1982, redrawn from original description; setae not illustrated; original illustration asymmetrical (Mey 1982). 33. Ventral view of female terminalia and vulval margin of Talegallipeurus tenuis Mey, 1982, redrawn from original description; setae not illustrated. 34. Outline of male paramere of Sinolipeurus tetraophasis (Clay, 1938), redrawn and simplified from Gustafsson et al. (2020). 35. Outline of male terminalia and stylus of Sinolipeurus tetraophasis (Clay, 1938), redrawn and simplified from Gustafsson et al. (2020). 36. Outline of male paramere of Reticulipeurus ithaginis (Clay, 1938), redrawn and simplified from Gustafsson et al. (2020). 37. Distal section of male genitalia of Epicolinus clavatus (McGregor, 1917), redrawn from Carriker (1945). Abbreviations used: AL = anterior lobes; $\mathrm{CL}=$ "claspers"; DPAS = dorsal post-antennal suture; IX-XI = tergopleurites IX-XI; $\mathrm{STY}=$ stylus; $\mathrm{VM}=$ vulval margin; $\mathrm{Y}=\mathrm{Y}$-shaped thickening. Antennae not included in any illustration. Illustrations are not to scale. 
12. Male parameres strongly S-curved (Fig. 34); stylus arising centrally on abdominal segment IX $+X$ (Fig. 35)

Sinolipeurus Gustafsson et al., 2020

- Male parameres not S-curved (Fig. 36); stylus varying in shape, but always arising terminally or subterminally on subgenital plate (similar to Fig. 3)

13. Male genitalia simple, with parameres fused to basal apodeme and mesosome much reduced (Fig. 37) .

Epicolinus Carriker, 1945

- Male genitalia with parameres articulating with basal apodeme, and mesosome not reduced (similar in structure but not shape to Fig. 8) .

14. Lateral margins of postantennal head with secondary, ventral carina between antennal socket and site of $m t s 2$ or $m t s 3$ (Fig. 38); area between margin of head and secondary carina, densely reticulated, including ventral surface of eye (Fig. 38); male parameres with pst1-2 situated close together apically; male gonoporal complex does not reach distal margin of mesosome; female subgenital plate divided medianly (Fig. 39)....

Valimia Gustafsson \& Zou, 2020

- Lateral margins of postantennal head without secondary carina and without extensive ventral reticulation (similar to Fig. 5); male parameres with pst1-2 separated, and only pst 2 apical; male gonoporal complex reached to or beyond distal margin of mesosome; female subgenital plate medianly continuous (Fig. 40)

Cataphractomimus Gustafsson et al., 2020

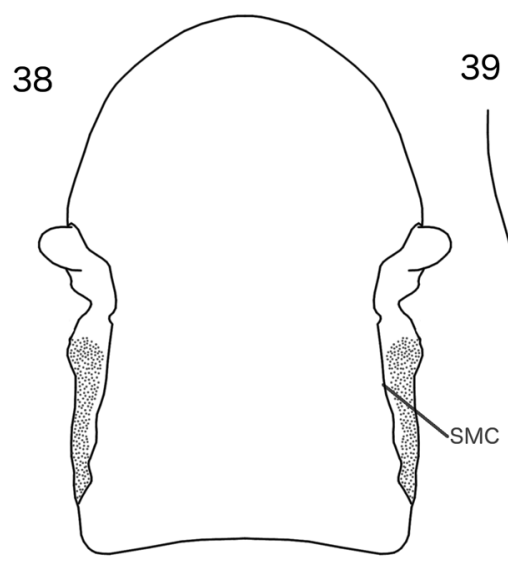

39
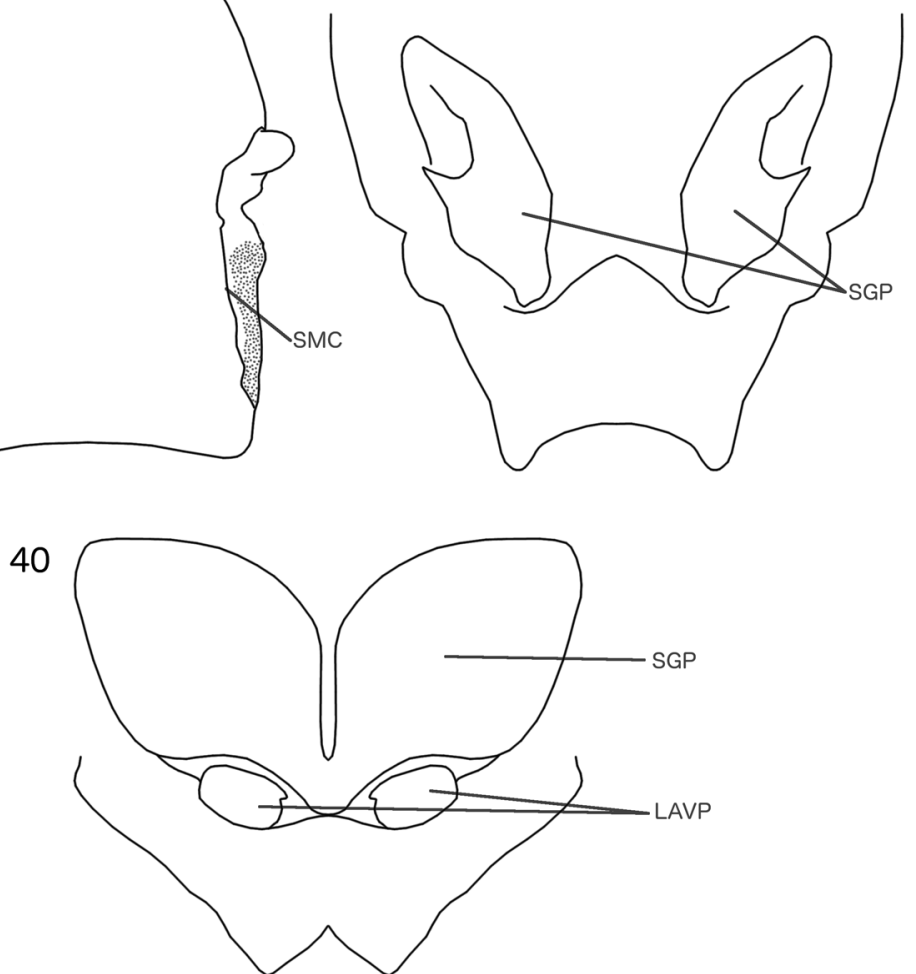

Figs 38-40. 38. Outline of male head of Valimia polytrapezius (Burmeister, 1838), with post-antennal ventral carina and densely reticulated area marked with grey dots; other characters omitted. 39. Outline of ventral view of female terminalia of "Oxylipeurus polytrapezius" (Burmeister, 1838). Setae not illustrated. (38-39 redrawn from Gustafsson \& Zou 2020b) 40. Outline of ventral view of female terminalia of Cataphractomimus impervius Gustafsson et al., 2020, redrawn and simplified from the original description. Antennae not included in any illustration. Abbreviations used: LAVP = lateral accessory vulval plates; $\mathrm{SGP}=$ subgenital plate; $\mathrm{SMC}=$ secondary marginal carina. Illustrations are not to scale. 


\section{Discussion}

Clay (1938) included illustrations of only a few species of Oxylipeurus and most of these illustrations are partial. As Clay (1938) is the only comprehensive revision of the genus, particularly for the Old World species, the systematics of this group has been confused, and most recent authors have adopted an overly conservative approach (e.g., Price et al. 2003). The complex includes a large number of morphologically homogeneous groups, some of which Clay (1938) considered species groups. Most of these species groups are distinct enough to warrant recognition at the genus level and a thorough revision of the complex is needed. Within this complex, the following genera should be recognized as valid: Afrilipeurus Mey, 2010; Calidolipeurus gen. nov.; Cataphractomimus Gustafsson et al., 2020; Chelopistes Kéler, 1939; Eiconolipeurus Carriker, 1945; Epicolinus Carriker, 1945; Gallancyra Gustafsson \& Zou, 2020; Megalipeurus Kéler, 1958; Oxylipeurus Mjöberg, 1910; Reticulipeurus Kéler, 1958; Sinolipeurus Gustafsson et al., 2020; Splendoroffula Clay \& Meinertzhagen, 1941; Talegallipeurus Mey, 1982; Trichodomedea Carriker, 1946 and Valimia Gustafsson \& Zou, 2020. Additional morphologically distinct groups exist within this complex, which represent undescribed genera.

\section{Acknowledgements}

Work was funded by the Introduction of Full-Time High-Level Talent Fund of the Guangdong Academy of Sciences grant 2018GDASCX-0809, GDAS Special Project of Science and Technology Development grants 2018GDASCX-0107 and GIABR-GJRC201701, and the National Natural Science Foundation of China grant 31961123003 . These agencies had no hand in the design or execution of this study and we declare no conflict of interest. We would like to thank two anonymous reviewers for helpful comments on this manuscript. We would like to thank Dr Vince Smith and Paul Brown (NHMUK) who hosted DRG in London and enabled the loan of specimens that this manuscript is based on.

\section{References}

Carriker M.A., Jr. 1945. Studies in Neotropical Mallophaga (V) The lipeuroid forms of the New World "Galliformes". Part 1. Revista Brasileira de Biologia 4: 537-585.

Carriker M.A., Jr. 1946. Studies in Neotropical Mallophaga (VII) Goniodes and allied genera from gallinaceous hosts. Revista de le Academia Colombiana de Sciencias Exactas (Bogotá) 6: 355-399.

Carriker M.A., Jr. 1967. New species of Colinicola, Passonomedea, Eiconolipeurus, and Oxylipeurus (Mallophaga: Philopteridae) from neotropical gallinaceous birds. United States National Museum Bulletin 248: 46-55.

Clay T. 1938. A revision of the genera and species of Mallophaga occurring on Gallinaceous hosts. Part I. Lipeurus and related genera. Proceedings of the Zoological Society of London 108: 108-204.

Clay T. \& Meinertzhagen R. 1941. Mallophaga miscellany. - No. 2. Annals and Magazine of Natural History 40: 329-346. https://doi.org/10.1080/00222934108527162

Elbel R.E. \& Price R.D. 1970. Two new species of ischnoceran Mallophaga from an oriental partridge (Mallophaga: Philopteridae). Journal of the Kansas Entomological Society 43: 238-242.

Emerson K.C. \& Ward R.A. 1958. Notes on Philippine Mallophaga, I. Species from Ciconiiformes, Anseriformes, Falconiformes, Galliformes, Gruiformes and Charadriiformes. Fieldiana - Zoology 42: $49-61$.

Gustafsson D.R. \& Bush S.E. 2017. Morphological revision of the hyperdiverse Brueelia-complex (Insecta: Phthiraptera: Ischnocera: Philopteridae) with new taxa, checklists and generic key. Zootaxa 4313: 1-443. https://doi.org/10.11646/zootaxa.4313.1.1 
Gustafsson D.R. \& Zou F. 2020a. Gallancyra gen. nov. (Phthiraptera: Ischnocera), with an overview of the geographical distribution of chewing lice parasitizing chicken. European Journal of Taxonomy 685: 1-36. https://doi.org/10.5852/ejt.2020.685

Gustafsson D.R. \& Zou F. 2020b. Descriptions of three congeneric species of chewing lice of the Oxylipeurus-complex (Insecta: Phthiraptera: Philopteridae) from the turkey, Meleagris gallopavo, including a new genus and a new species. Zootaxa 4801: 488-512.

https://doi.org/10.11646/zootaxa.4801.3.4

Gustafsson D.R., Lei L., Chu X. \& Zou F. 2020. Review of the Chinese species of the Oxylipeuruscomplex (Phthiraptera: Philopteridae), with descriptions of two new genera and five new species. Zootaxa 4742: 201-255. https://doi.org/10.11646/zootaxa.4742.2.1

Harrison L. 1916. The genera and species of Mallophaga. Parasitology 9: 1-156. https://doi.org/10.1017/S0031182000005989

Hopkins G.H. \& Clay T. 1952. A Check List of the Genera and Species of Mallophaga. British Museum (Natural History), London.

Kéler S. von. 1939. Baustoffe zu einer Monographie der Mallophagen. II. Teil: Überfamilie der Nirmoidea (1). Die Familien Trichophilopteridae, Goniodidae, Heptapsogastridae. Nova Acta Leopoldina. Abhandlungen der Kaiserlischen Leopoldinisch-Carolinisch Deutschen Akademie der Naturforscher, Neue Folge 8: 1-254.

Kéler S. von. 1958. The genera Oxylipeurus Mjöberg and Splendoroffula Clay and Meinertzhagen (Mallophaga). Deutsche Entomologische Zeitschrift, Neue Folge 5: 300-347.

Ledger J.A. 1980. Phthiraptera (Insecta). Volume IV of the Arthropod Parasites of Vertebrates in Africa South of the Sahara. Publications of the South African Institute for Medical Research 56. South African Institute for Medical Research, Johannesburg.

Madge S. \& McGowan P. 2002. Pheasants, Partridges and Grouse. A Guide to the Pheasants, Partridges, Quails, Grouse, Guineafowl, Buttonquails, and Sandgrouse of the World. Christopher Helm, London.

Mey E. 1982. Zur Taxonomie und Biologie der Mallophagen von Talegalla jobiensis longicaudus A.B. Meyer, 1891 (Aves, Megapodiidae). Reichenbachiana, Staatliches Museum für Tierkunde in Dresden 20: $223-246$.

Mey E. 1990. Zur Taxonomie der auf Großfußhühnern (Megapodiidae) schmarotzenden OxylipeurusArten (Insecta, Phthiraptera, Ischnocera: Lipeuridae). Zoologische Abhandlungen Staatliches Museum für Tierkunde Dresden 46: 103-116.

Mey E. 2006. Rätselhaftes Vorkommen zweier Federlingsarten (Insecta, Phthiraptera, Ischnocera) auf dem Haldenhuhn Lerwa lerwa (Galliformes, Phasianidae)? In: Hartmann M. \& Weipert J. (eds) Biodiversität und Naturausstattung im Himalaya. Naturkundemuseum Erfurt, Germany.

Mey E. 2009. Die Mallophagen (Insecta, Phthiraptera: Amblycera \& Ischnocera) der Galloanseres (Aves) - ein Überblick. Beiträge zur Jagd und Wild Forschung 34: 151-187.

Mey E. 2010. Afrilipeurus novum genus pro Oxylipeurus vincentei v. Kéler (Insecta, Phthiraptera, Ischnocera, Philopteridae s. 1.) vom Kräuselhauben-Perlhuhn Guttera pucherani (Hartlaub). Rudolstädter naturhistorische Schriften 16: 99-110.

Mjöberg, E. 1910. Studien über Mallophagen und Anopluren. Arkiv för Zoologi 6: 1-150.

Piaget E. 1880. Les Pédiculines. Essai monographique. E.J. Brill, Leiden.

Price R.D., Hellenthal R.A. \& Palma R.L. 2003. World checklist of chewing lice with host associations and keys to families and genera. In: Price R.D., Hellenthal R.A., Palma R.L., Johnson K.P. \& Clayton D.H. 
(eds) The Chewing Lice: World Checklist and Biological Overview. Illinois Natural History Survey Special Publication 24. Illinois Natural History Survey, Champaign, Illinois.

Wang N., Kimball R.T., Braun E.L., Liang B. \& Zhang Z. 2013. Assessing phylogenetic relationships among Galliformes: a multigene phylogeny with expanded taxon sampling in Phasianidae. PLoS ONE: e64312. https://doi.org/10.1371/journal.pone.0064312

Manuscript received: 18 November 2019

Manuscript accepted: 4 May 2020

Published on: 15 July 2020

Topic editor: Nesrine Akkari

Desk editor: Kristiaan Hoedemakers

Printed versions of all papers are also deposited in the libraries of the institutes that are members of the EJT consortium: Muséum national d'histoire naturelle, Paris, France; Meise Botanic Garden, Belgium; Royal Museum for Central Africa, Tervuren, Belgium; Royal Belgian Institute of Natural Sciences, Brussels, Belgium; Natural History Museum of Denmark, Copenhagen, Denmark; Naturalis Biodiversity Center, Leiden, the Netherlands; Museo Nacional de Ciencias Naturales-CSIC, Madrid, Spain; Real Jardín Botánico de Madrid CSIC, Spain; Zoological Research Museum Alexander Koenig, Bonn, Germany; National Museum, Prague, Czech Republic. 